\title{
Evaluation of Dahlia Genotypes for Growth and Yield Characters under Dry Zone of Karnataka, India
}

\author{
Jyoti Verma $^{1^{*}}$ and Balaji S. Kulkarni ${ }^{2}$ \\ ${ }^{1}$ Department of Floriculture and Landscape Architecture, Kittur Rani Channamma College of \\ Horticulture, Arabhavi - 591307, Karnataka, India \\ ${ }^{2}$ Department of Floriculture and Landscape Architecture, College of Horticulture, GKVK Post, \\ Bengaluru - 560065, Karnataka, India \\ *Corresponding author
}

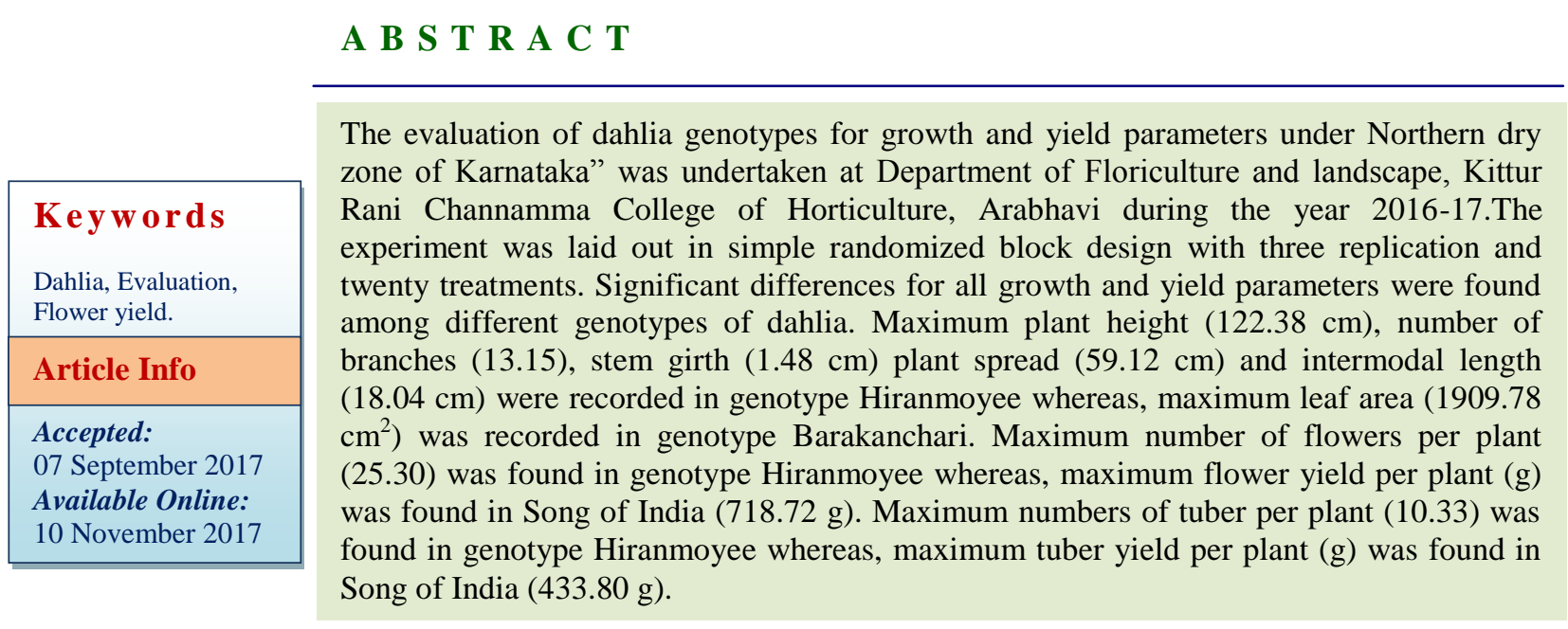

\section{Introduction}

Dahlia (Dahlia variabilis L.) is one of the most popular tuberous rooted perennial, herbaceous flowering plants, valued for their gorgeous attractive spectacular flowers. This plant is being grown in many parts of the world for its beautiful ornamental blooms of varying shades of colours for the beautification of gardens, for cut flowers and as a loose flower. It belongs to the family Asteraceae. Dahlia originated in Mexico, which received its name by Cavanilles in the year 1791, to commemorate the work of a Swedish Botanist Dr. Andreas Dahl, a pupil of Linneaus (Smith, 1971).Dahlia was introduced to India as early as 1857 under the auspices of the Agri-Horticultural Society of India (formerly, Royal Agri - Horticultural Society of India).

The height of dahlia plants varies from 30 to $180 \mathrm{~cm}$ depending upon the cultivar.

Dahlia flower consists of a certain number of outer ray florets in which the male organs are modified in to a strap shaped petal, arranged round a central disk of bisexual florets. 
Dahlia occupies a place of pride in any garden anywhere. Dahlias are easy to grow both in field and in pot and all types of dahlias are extensively used for exhibition, garden display and home decoration.

Dwarf growing types are suitable for flower beds and borders (pure or mixed borders) whereas, large flowering dahlia for pot. Cut flowers of pompon and miniature types stay fresh in flower vases for many days and better to make moderately good garlands and to use as individual loose flower.

As Dahlia is still called an uncut diamond for India, evaluation is the stepping stone in order to utilize any crop to its full potential. Since the performance of each genotype varies with region, season and growing environment, therefore testing the performance of the available genotypes for suitability and adaptability take prime importance, as the research works on this line is meagre in Northern parts of Karnataka. Keeping all these points in view an investigation was carried out to assess the performance of different genotypes for their growth and yield traits.

\section{Materials and Methods}

The present investigation entitled "Evaluation of Dahlia (Dahlia variabilis L.) Genotypes for Growth and Yield Characters Under Northern Dry Zone of Karnataka" was undertaken at Department of Floriculture and landscape, Kittur Rani Channamma College of Horticulture, Arabhavi during the year 201617.The experiment was laid out in simple randomized block design with three replication and twenty treatments. Thirty days old rooted cuttings were transplanted on the main field with a spacing of $60 \times 45 \mathrm{~cm}$. Observations were recorded on five randomly selected plants in each replication after 120 days of transplanting.

\section{Results and Discussion}

\section{Growth parameters}

The vegetative growth was measured in terms of plant height $(\mathrm{cm})$, number of branches, stem girth $(\mathrm{cm})$, plant spread $(\mathrm{cm})$, intermodal length $(\mathrm{cm})$ and leaf area $\left(\mathrm{cm}^{2}\right)$ (Table 1).

Among the 20 genotypes evaluated, Plant height was significantly influenced by different genotypes throughout the experimental period (Table 1). The genotypes Hiranmoyee, Song of India, Priyasona White and Kamala were vigorous in growth in terms of plant height. The genotype Budhha recorded minimum plant height. Plant height being a genetically controlled factor, it varied among the genotypes as well as influence of the growing environmental conditions, production technology and cultural practices. Similar variation in plant height due to cultivars was also observed in dahlia by Syamal and Kumar (2002) and Vikas et al., (2015), in China aster by Munikrishnappa (2013), Chowdhuri et al., (2015) and Chourasia et al., (2015) in gladiolus.

Significant difference with respect to number of branches produced per plant was noticed (Table 1). Number of branches was more in genotype Hiranmoyee and Song of India while, the ACC-6 recorded minimum branches. The difference in number of branches could be attributed to the genetic makeup of the cultivars. Increased number of branches leads to production of more number of leaves in turn it will enhance the yield of flowers and tubers by increasing source and sink relationship. Similar trend was noticed by Gupta et al., (2015) in dahlia and Munikrishnappa (2013) and Chowdhuri et al., (2015) in different China aster genotypes.

Significant difference with respect to stem girth was noticed (Table 1). 
Table.1 Performance of dahlia genotypes for growth parameters

\begin{tabular}{|c|c|c|c|c|c|c|}
\hline Genotypes & $\begin{array}{c}\text { Plant height } \\
(\mathrm{cm})\end{array}$ & $\begin{array}{c}\text { Number of } \\
\text { branches }\end{array}$ & Stem girth & $\begin{array}{c}\text { Plant spread } \\
(\mathrm{cm})\end{array}$ & $\begin{array}{c}\begin{array}{c}\text { Internodal length } \\
(\mathrm{cm})\end{array} \\
\end{array}$ & $\begin{array}{c}\begin{array}{c}\text { Leaf area } \\
\left(\mathrm{cm}^{2}\right)\end{array} \\
\end{array}$ \\
\hline ACC-1 & 112.81 & 12.11 & 1.31 & 51.19 & 16.7 & 1066.8 \\
\hline ACC-2 & 106.83 & 10.39 & 1.37 & 41.96 & 16.02 & 1302.84 \\
\hline ACC-3 & 104.91 & 10.75 & 1.38 & 44.21 & 15.89 & 1049.24 \\
\hline ACC-4 & 103.48 & 10.55 & 1.25 & 44.44 & 15.59 & 1059 \\
\hline ACC-5 & 111.33 & 10.15 & 1.37 & 43.64 & 16.5 & 1222.4 \\
\hline ACC-6 & 102.04 & 7.15 & 1.21 & 32.99 & 12.84 & 960.75 \\
\hline ACC-7 & 101.44 & 7.8 & 1.28 & 38.32 & 15.31 & 1181.88 \\
\hline ACC-8 & 101.63 & 9.66 & 1.33 & 40.23 & 15.36 & 1566.74 \\
\hline ACC-9 & 104.65 & 10.04 & 1.35 & 41.38 & 15.7 & 1241.8 \\
\hline ACC-10 & 101.97 & 8.62 & 1.3 & 40.12 & 15.44 & 1055.7 \\
\hline ACC-11 & 98.9 & 7.58 & 1.27 & 33.6 & 13.43 & 1126.4 \\
\hline Kamala & 118.55 & 12.37 & 1.33 & 49.63 & 17.01 & 1506.78 \\
\hline Song of India & 121.17 & 12.73 & 1.44 & 57.23 & 17.74 & 1867.39 \\
\hline Niladri & 92.26 & 11.49 & 1.38 & 37.9 & 15.27 & 1541.12 \\
\hline Budhha & 87.07 & 11.14 & 1.36 & 35.02 & 14.96 & 1403.13 \\
\hline Kucha & 110.72 & 11.65 & 1.36 & 46.6 & 16.31 & 1433.55 \\
\hline Hiranmoyee & 122.38 & 13.15 & 1.48 & 59.12 & 18.04 & 1279.32 \\
\hline Barakanchari & 112.14 & 11.99 & 1.43 & 47.21 & 16.64 & 1909.28 \\
\hline Priyasona White & 119.12 & 12.52 & 1.45 & 51.33 & 17.61 & 1755.36 \\
\hline Zail Singh & 107.67 & 11.54 & 1.4 & 46.32 & 16.12 & 1244.69 \\
\hline Mean & 107.05 & 10.67 & 1.35 & 44.12 & 15.92 & 1338.73 \\
\hline S.Em \pm & 1.92 & 0.31 & 0.05 & 1.72 & 0.69 & 40.53 \\
\hline CD at $5 \%$ & 5.5 & 0.91 & 0.12 & 4.94 & 2.00 & 116 \\
\hline
\end{tabular}


Table.2 Flower yield parameters in different dahlia genotypes

\begin{tabular}{|c|c|c|c|c|}
\hline Genotypes & Number of flowers/plant & Flower yield/ha (lakhs) & Flower yield /plant (g) & Flower yield/ha (t) \\
\hline ACC-1 & 20.60 & 7.63 & 361.87 & 13.35 \\
\hline ACC-2 & 17.70 & 6.55 & 344.73 & 12.78 \\
\hline $\mathrm{ACC}-4$ & 14.90 & 5.52 & 223.13 & 8.27 \\
\hline ACC-5 & 20.10 & 7.44 & 229.14 & 8.50 \\
\hline ACC-8 & 17.48 & 6.47 & 188.10 & 6.93 \\
\hline ACC-9 & 15.20 & 5.63 & 213.65 & 7.98 \\
\hline $\mathrm{ACC}-10$ & 19.60 & 7.26 & 272.58 & 10.08 \\
\hline $\mathrm{ACC}-11$ & 14.30 & 5.30 & 167.37 & 6.17 \\
\hline Budhha & 20.00 & 7.41 & 494.10 & 18.32 \\
\hline Kucha & 19.40 & 7.15 & 491.53 & 18.10 \\
\hline Hiranmoyee & 25.30 & 9.37 & 691.42 & 25.60 \\
\hline Barakanchari & 20.00 & 7.41 & 569.65 & 21.12 \\
\hline Priyasona White & 23.70 & 8.69 & 553.30 & 20.37 \\
\hline Zail Singh & 21.00 & 8.15 & 455.91 & 17.71 \\
\hline Mean & 19.37 & 7.18 & 358.87 & 13.31 \\
\hline S.Em \pm & 1.09 & 0.25 & 25.64 & 0.67 \\
\hline CD at $5 \%$ & 3.11 & 0.72 & 73.39 & 1.91 \\
\hline
\end{tabular}


Table.3 Tuber yield parameters in different dahlia genotypes

\begin{tabular}{|c|c|c|c|c|c|}
\hline Genotypes & $\begin{array}{c}\text { Number of } \\
\text { tubers/plant }\end{array}$ & $\begin{array}{c}\text { Tuber yield/ha } \\
\text { (lakhs) }\end{array}$ & $\begin{array}{c}\text { Individual tuber } \\
\text { weight }(\mathrm{g})\end{array}$ & $\begin{array}{c}\text { Tuber } \\
\text { yield/plant (g) }\end{array}$ & $\begin{array}{c}\text { Tuber yield/ha } \\
\text { (t) }\end{array}$ \\
\hline ACC-1 & 7.33 & 2.71 & 43.33 & 310.97 & 11.52 \\
\hline ACC-2 & 4.38 & 1.62 & 60.00 & 263.40 & 9.76 \\
\hline ACC-3 & 6.06 & 2.24 & 40.83 & 336.63 & 12.47 \\
\hline ACC-4 & 5.65 & 2.09 & 53.33 & 305.31 & 11.31 \\
\hline ACC-5 & 4.85 & 1.80 & 45.00 & 221.58 & 8.21 \\
\hline ACC-6 & 4.05 & 1.50 & 41.33 & 170.72 & 6.32 \\
\hline ACC-7 & 5.00 & 1.85 & 53.11 & 273.55 & 10.13 \\
\hline ACC-8 & 4.65 & 1.72 & 43.66 & 206.70 & 7.66 \\
\hline ACC-9 & 5.00 & 1.85 & 52.50 & 266.50 & 9.87 \\
\hline ACC-10 & 4.20 & 1.56 & 50.00 & 206.67 & 7.65 \\
\hline ACC-11 & 4.22 & 1.56 & 40.50 & 172.58 & 6.39 \\
\hline Kamala & 5.90 & 2.19 & 56.66 & 330.96 & 12.26 \\
\hline Song of India & 7.33 & 2.72 & 59.20 & 433.80 & 16.07 \\
\hline Niladri & 5.85 & 2.17 & 52.50 & 302.13 & 11.19 \\
\hline Budhha & 6.05 & 2.24 & 48.65 & 289.00 & 10.70 \\
\hline Kucha & 6.45 & 2.39 & 56.66 & 358.12 & 13.26 \\
\hline Hiranmoyee & 8.78 & 3.25 & 55.00 & 349.45 & 12.94 \\
\hline Barakanchari & 7.00 & 2.59 & 55.50 & 400.50 & 14.83 \\
\hline Priyasona White & 5.45 & 2.02 & 52.50 & 292.79 & 10.84 \\
\hline Zail Singh & 6.66 & 2.47 & 55.83 & 378.49 & 14.02 \\
\hline Mean & 5.74 & 2.13 & 50.80 & 293.49 & 10.87 \\
\hline S.Em \pm & 0.70 & 0.26 & 4.02 & 40.09 & 1.48 \\
\hline CD at $5 \%$ & 2.01 & 0.75 & 11.51 & 114.78 & 4.25 \\
\hline
\end{tabular}


Stem girth should be more to have sturdiness of the plant. Otherwise the weak and thin stem may lead to lodging of plants in windy situations. Genotypes Hiranmoyee, Priyasona White and Song of India had higher stem girth at all the growth stages, whereas ACC-6 and ACC-7 recorded the lowest stem girth. Similar trend was observed by Vikas et al., (2015) in dahlia and Yadav et al., (2007) in chrysanthemum genotypes.

Plant spread is an important growth factor for flower crops. It helps to utilize the sunlight to maximum extent. Plant spread during different growth periods varied significantly among the dahlia genotypes. Maximum plant spread was recorded in genotypes Hiranmoyee and Song of India throughout the period. This may due to more number of branches produced by these genotypes and vigorous growth character. Whereas, the genotype Niladri produced minimum plant spread and this may be due to varietal differences and less vigorous in growth. Similar results were recorded by Kumar et al., (2010) and Gupta et al., (2015) in dahlia.

Significant difference with respect to internodal length was noticed (Table 1). The internodal length was more in the genotypes Hiranmoyee and Song of India hence the plants were more in height. The genotype ACC-6 and ACC-11 recorded least internodal length. The variation in internodal length among the cultivars may be due to genetic makeup of the cultivars and higher the intermodal length more will be the plant height. Similar results were observed in China aster by Zosiamliana et al., (2012).

Leaf area was significantly influenced by the genotypes. Among the different genotypes, leaf area was more in Barakanchari and Song of India whereas, least in ACC-6. Similar variation was also observed by Shruti et al., (2004) and Anop et al., (2010) in gerbera.

\section{Yield parameter}

Yield parameters decide the significance of suitability of the particular genotypes for commercial cultivation and significant difference was noticed for all the yield parameters (Tables 2 and 3).

Maximum numbers of flowers per plant were produced in genotypes Hiranmoyee Song of India, Priyasona White and Kamala. Whereas, the minimum number of flowers were in ACC-6. The same trend was followed for flower yield per hectare. The number of flowers produced per plant may be directly related to increase in plant height, number of branches and number of leaves and ultimately accumulation of more photosynthates which results in production of good number of flowers with bigger size. The similar results were observed in dahlia by Ahmed and Gul (2002), in China aster by Munikrishnappa (2013) and Zosiamliana et al., (2012).

Flowers yield per plant (g) and per hectare (t) was recorded highest in genotypes Song of India and Hiranmoyee. Whereas, it was recorded minimum in ACC-6. The number of flowers produced per plant may be directly related to increase in plant height, number of branches and number of leaves and ultimately accumulation of more photosynthates which results in production of good number of flowers. The similar results were observed in dahlia by Gupta et al., (2015), in China aster by Tirakannanavar et al., (2015) and Rajiv (2014) in chrysanthemum.

Maximum number of tubers per plant was produced in genotypes Hiranmoyee, Song of India and Barakanchari while, least number of tubers was obtained in ACC-6. The number of tubers produced per plant may be directly related to production of more plant height, number of branches, there by synthesis of more photosynthates result in production of 
good number of developed flower buds on the branches finally to the production of tubers. The similar results observed in dahlia by Ahmed and Gul (2002) and in gladiolus by Chopde et al., (2012).

Tuber yield per plant (g) and per hectare (t) was obtained in genotypes Hiranmoyee, Song of India and least was obtained in ACC-6. Tuber yield per plant may be directly related to production of more plant height, number of branches, there by synthesis of more photosynthates and ultimately good tuber yield. The similar results observed in dahlia by Gupta et al., (2015) and in gladiolus by Chopde et al., (2012).

Tuber weight per plant showed significant difference among different genotypes of dahlia. It was highest in ACC-2, Song of India, and least was noticed in ACC-11. The variation in tuber weight may be due to the genotypic expression of the genotypes. This is in accordance with results of Manjula et al., (2017) in dahlia.

\section{Acknowledgement}

The authors sincerely acknowledge department of Floriculture and Landscape Architecture for providing the facilities.

\section{References}

Ahmed, M. J. and Gul, S., 2002, Evaluation of exotic cultivars of dahlia (Dahlia coccinea) under rawalakot conditions. Asian J. Plant sci., 1(5): 565-566.

Anop, K., Patel, K. S. and Nayee, D. D., 2010, Evaluation of different cultivars of gerbera (Gerbera jamisonii B.) for growth, yield and quality grown under fan and pad cooled greenhouse conditions. Asian J. Hort., 5(2): 309310.

Chopde, N., Gawali, R. P. and Thakre, S.,
2012, Evaluation of gladiolus varieties for flower and corm production under vidarbha conditions. Plant Archives, 12(2): 911-913.

Chourasia, A., Viradia, R. R., Ansar, H. and Shubham, N. M., 2015, Evaluation of different gladiolus cultivars for, growth, flowering, spike yield and corm yield under Saurashtra region of Gujarat. Int. Quart J. Life Sci., 10(1): 131-134.

Chowdhuri, T. K., Rout, B., Sadhukhan, R. and Mondal, T., 2015, Performance evaluation of different varieties of China aster (Callistephus chinensis L. Ness.) in Sub tropical belt of West Bengal. Int. J. Pharm. Sci. Invent., 5(8): $15-18$

Gupta, A. K., Jaiswal, N. K. and Saravanan, S., 2015, Varietal evaluation of different hybrids of Dahlia (Dahlia variabilis L.). Int. J. Agric. Sci. Res., 5(1): 55-58.

Kumar, L., Mahawer, L. N., Shukla, A. K., Kaushik, R. A. and Upadhyay, B., 2010, To evaluate the dahlia cultivars for vegetative, floral and relative economic parameters. Prog. Hort., 42(2): 157-161.

Manjula, B. S., Nataraj, S. K., Hegde, P. P., Anitha, G. and Ayesha, N., 2017, Evaluation of dahlia genotypes (dahlia variabilis L.) for growth, yield and quality traits under hill zone of Karnataka. J. Environ. Ecol. 35(4a): 365-369.

Munikrishnappa, P. M., Patil, A. A., Patil, V. S., Patil, B. N., Channappagoudar, B. B. and Alloli, T. B., 2013, Studies on the growth and yield parameters of different genotypes of China aster (Callistephus chinensis Nees.). Karnataka J. Agric. Sci., 26(1): 107-110.

Rajiv, K., 2014, Evaluation of chrysanthemum genotypes for flowering traits under open grown condition. Hort. Flora Res. Spectrum, 3(4): 388-389. 
Shruti, W., Golliwar, V. J., Shital, D., Manjusha, A. and Nisha, B., 2004, Performance of gerbera varieties under shadenet. J. Soils Crops, 14(2): 383387.

Smith, A. W., 1971, In: A Gardener's Dictionary of Plant Names. Cassell and Company Ltd, London, p. 390.

Syamal, M. M. and Kumar, A., 2002, Genetic variability and correlation studies in dahlia. J. Orn. Hort., New Series, 5(1): 40-42.

Tirakannanavar, S., Katagi, A., Jagadeesha, R. C. and Halesh, G. K., 2015, Studies on genotypic evaluation and correlation studies in China aster [Callistephus chinensis (L.) Nees.]. Indian Res. J. Genet. Biotech, 7(2): 179-186.
Vikas, H. M., Patil, V. S. and Dorajeerao, A. V. D., 2015, Evaluation of dahlia genotypes based on vegetative quality character. Plant Archives, 15(1): 283286.

Yadav, D. S., Rajiv, K. and Roy, A. R., 2007, Performance of chrysanthemum (Dendrathema grandiflora Tzvelcv.) cultivars under subtropical midhills altitude of Meghalaya. Environ. Ecol., 255(Special 34): 941-944.

Zosiamliana, J. H., Reddy, G. S. N. and Rymbai, H., 2012, Growth, flowering and yield characters of some cultivars of China aster (Callistephus chinensis Nees.). J. Nat. Prod. Plant Resour, 2(2): 302-305.

\section{How to cite this article:}

Jyoti Verma and Balaji S. Kulkarni. 2017. Evaluation of Dahlia Genotypes for Growth and Yield Characters under Dry Zone of Karnataka. Int.J.Curr.Microbiol.App.Sci. 6(11): 402-409. doi: https://doi.org/10.20546/ijcmas.2017.611.046 